\title{
Development of Porcine Somatic Cell Nuclear Transfer Embryos Following Treatment Time of Endoplasmic Reticulum Stress Inhibitor
}

\begin{tabular}{|l|} 
Check for \\
updates
\end{tabular}

Received: January 14, 2021

Revised: January 23, 2021

Accepted: January 30, 2021

\section{${ }^{\dagger}$ Corresponding author}

Hee-Tae Cheong

College of Veterinary Medicine, Kangwon

National University, Chuncheon 24341,

Korea.

Tel: +82-33-250-8659

E-mail: htcheong@kangwon.ac.kr

Copyright $\odot 2021$ The Korean Society of Developmental Biology.

This is an Open Access article distributed under the terms of the Creative Commons Attribution Non-Commercial License (http://creativecommons.org/licenses/ by-nc/4.0/) which permits unrestricted non-commercial use, distribution, and reproduction in any medium, provided the original work is properly cited.

ORCID

Mi-Jeong Kim

https://orcid.org/0000-0002-7244-4781

Bae-Dong Jung

https://orcid.org/0000-0002-6653-9928

Choon-Keun Park

https://orcid.org/0000-0003-2786-8814

Hee-Tae Cheong

https://orcid.org/0000-0001-8225-0262

Conflict of interests

The authors declare no potential conflict of interest.

\section{Acknowledgements}

This study was supported by Basic Science Research Program through the National Research Foundation of Korea (NRF) funded by the Ministry of Education (2016R1D1A1B03930662).

\author{
Mi-Jeong Kim ${ }^{1}$, Bae-Dong Jung ${ }^{1}$, Choon-Keun Park ${ }^{2}$, and ${ }^{\dagger}$ Hee-Tae Cheong ${ }^{1}$ \\ ${ }^{1}$ College of Veterinary Medicine and Institute of Veterinary Science, Kangwon National University, Chuncheon 24341, \\ Korea \\ ${ }^{2}$ College of Animal Life Sciences, Kangwon National University, Chuncheon 24341, Korea
}

\section{Abstract}

We examine the effect of endoplasmic reticulum (ER) stress inhibitor treatment time on the in vitro development of porcine somatic cell nuclear transfer (SCNT) embryos. Porcine SCNT embryos were classified by four groups following treatment time of ER stress inhibitor, tauroursodeoxycholic acid (TUDCA; $100 \mu \mathrm{M}) ; 1$ ) non-treatment group (control), 2) treatment during micromanipulation process and for $3 \mathrm{~h}$ after fusion (NT+3 $\mathrm{h}$ group), 3) treatment only during in vitro culture after fusion (IVC group), and 4) treatment during micromanipulation process and in vitro culture (NT+IVC group). SCNT embryos were cultured for six days to examine the X-box binding protein 1 (Xbp1) splicing levels, the expression levels of ER stress-associated genes, oxidative stress-related genes, and apoptosis-related genes in blastocysts, and in vitro development. There was no significant difference in Xbp1 splicing level among all groups. Reduced expression of some ER stress-associated genes was observed in the treatment groups. The oxidative stress and apoptosis-related genes were significantly lower in all treatment groups than control $(p<0.05)$. Although blastocyst development rates were not different among all groups (17.5\% to $21.7 \%)$, the average cell number in blastocysts increased significantly in NT+3 h $(48.5 \pm 2.3)$ and NT+IVC $(47.7 \pm 2.4)$ groups compared to those of control and IVC groups $(p<0.05)$. The result of this study suggests that the treatment of ER stress inhibitor on SCNT embryos from the micromanipulation process can improve the reprogramming efficiency of SCNT embryos by inhibiting the ER and oxidative stresses that may occur early in the SCNT process.

Keywords: Somatic cell nuclear transfer, Endoplasmic reticulum stress, Endoplasmic reticulum (ER) stress inhibitor, In vitro development, Pig

\section{INTRODUCTION}

Various cellular stresses induced by physical stimuli during somatic cell nuclear transfer (SCNT) process adversely affect the reprogramming of SCNT embryos (Morgan et al., 2005; Lee et al., 2018). The main cellular stresses include reactive oxygen species (ROS) and endoplasmic reticulum (ER) 
Authors' contributions

Conceptualization: Cheong HT.

Methodology: Kim MJ.

Software: Kim MJ.

Validation: Kim MJ.

Investigation: Kim MJ.

Writing-original draft: Kim MJ.

Writing-review \& editing: Jung BD, Park CK, Cheong HT.

Ethics approval

This article does not require IRB/IACUC approval because there are no human and animal participants. stress (Hwang et al., 2012; Lee et al., 2018; Park et al., 2020). ER and oxidative stresses promote each other, which disturbs cell function and activates pro-apoptotic signals (Malhotra \& Kaufman, 2007).

ER is responsible for protein synthesis and activation in the intracellular organelle. The accumulation of unfolded or misfolded proteins in the ER lumen can disorder ER homeostasis and cause ER stress (Boyce \& Yuan, 2006; Malhotra \& Kaufman, 2007). When ER stress occurs, unfolded protein response (UPR), which disrupts protein synthesis, decomposes unfolded proteins, and increases the expression of chaperones that cause the unfolded proteins to fold properly, reduces ER stress and restores normal function of the cells (Malhotra \& Kaufman, 2007). However, if the ER stress persists in a long time or is serious, pro-apoptotic gene is activated, leading to apoptosis. It has been reported that another cellular stress, oxidative stress, is also associated with ER stress (Cullinan \& Diehl, 2006). Under ER stress condition, formation and breakage of disulfide binding accumulate the ROS and cause oxidative stress (Sevier et al., 2001; Cullinan \& Diehl, 2006; Zhang et al., 2015).

Tauroursodeoxycholic acid (TUDCA), an ER stress inhibitor, has been found to reduce intracellular oxidative stress and inhibit cell apoptosis in various diseases (Xie et al., 2002). TUDCA is also reported to reduce cell apoptosis by counteracting ER stress and improve embryonic development in pig (Kim et al., 2012). TUDCA activates an activating transcription factor 6 (ATF6) to improve the folding capacity of misfolded/unfolded protein (Omura et al., 2013).

In general, ER stress inhibitor was treated during in vitro culture period of IVF embryos (Yoon et al., 2014), parthenogenetic embryos (Zhang et al., 2012), or SCNT embryos (Song et al., 2014; Lin et al., 2016) to improve the development of embryos. On the other hand, the development and quality of SCNT embryos were improved by treating an ER stress inhibitor during micromanipulation process of SCNT, by inhibiting ER stress generation and reducing apoptosis (Park et al., 2019; Park et al., 2020).

It is important to determine the appropriate treatment timing of ER stress inhibitor for the improved reprogramming of SCNT embryos. Thus, in this study, it was examined the effect of an ER stress inhibitor TUDCA treatment at various stage of the porcine SCNT procedure, such as micromanipulation, in vitro culture or both micromanipulation and in vitro culture periods.

\section{MATERIALS AND METHODS}

\section{Chemical}

All chemicals and reagents were purchased from the Sigma-Aldrich (St. Louis, MO, USA) unless otherwise indicated. TUDCA (Merck, Darmstadt, Germany) melted in dimethyl sulfoxide (Junsei Chemical, Tokyo, Japan) and stored at $-20^{\circ} \mathrm{C}$ until use.

\section{Oocyte collection and in vitro maturation}

Porcine cumulus-oocyte complexes (COCs) were aspirated from follicles (3-6 mm diameter) using a $10 \mathrm{~mL}$ syringe with an 18-gauge needle. COCs were washed in Tyrode's lactate (TL)Hepes medium containing $0.1 \%(\mathrm{w} / \mathrm{v})$ polyvinyl alcohol (PVA), and cultured in $500 \mu \mathrm{L}$ of in vitro maturation (IVM) medium at $39^{\circ} \mathrm{C}, 5 \% \mathrm{CO}_{2}$ in air for $42-44 \mathrm{~h}$. The IVM medium was Tissue Culture Medium 199 (TCM199; Gibco, Grand Island, NY, USA) supplemented with $3.05 \mathrm{mM}$ D-glucose, $0.91 \mathrm{mM}$ Na-pyruvate, $0.57 \mathrm{mM}$ cysteine, $0.1 \%$ (w/v) PVA, $75 \mu \mathrm{g} / \mathrm{mL}$ penicillin $\mathrm{G}, 50$ $\mu \mathrm{g} / \mathrm{mL}$ streptomycin, $0.01 \mathrm{IU} / \mathrm{mL}$ follicle stimulating hormone $(\mathrm{FSH}), 0.01 \mathrm{IU} / \mathrm{mL}$ luteinizing hormone (LH), and $10 \mathrm{ng} / \mathrm{mL}$ epidermal growth factor (EGF). 


\section{Preparation of donor somatic cells}

Porcine ear fibroblasts (PEFs) were cultured in Dulbecco's modified Eagle's medium (DMEM; Gibco) containing 15\% FBS (Gibco) and 1\% (w/v) penicillin/streptomycin (P/S; Mediatech, Manassas, VA, USA) at $39^{\circ} \mathrm{C}, 5 \% \mathrm{CO}_{2}$ in air until they reached at confluence to synchronize the cell cycle stage at the $\mathrm{G} 1$ phase. Cells were trypsinized with $0.05 \%$ (w/v) trypsin-EDTA (Gibco) and centrifuged $(500 \times \mathrm{g}$ ) for $4 \mathrm{~min}$ at room temperature in Hepes-buffered TCM199 containing 0.14 $\mathrm{mM}$ penicillin $\mathrm{G}, 0.78 \mathrm{mM} \mathrm{NaHCO}, 0.08 \mathrm{mM}$ streptomycin and $3 \mathrm{mg} / \mathrm{mL}$ BSA (TCM-BSA). Donor cells were placed in $500 \mu \mathrm{L}$ droplets of the same medium for use.

\section{Nuclear transfer}

The cumulus cells of oocytes were removed by vortexing in PBS (Gibco) containing with $0.1 \%(\mathrm{w} / \mathrm{v})$ polyvinyl pyrrolidone (PVP) and $0.1 \%(\mathrm{w} / \mathrm{v})$ hyaluronidase for $3 \mathrm{~min}$. The metaphase II oocytes were placed in a drop of micromanipulation medium of Hepes-buffered TCM-BSA containing $5 \mu \mathrm{g} / \mathrm{mL}$ cytochalasin B. Enucleation was carried out by removing the $1^{\text {st }}$ polar body and a small amount of surrounding cytoplasm including chromosome mass using an injection pipette. Subsequently, one donor cell was injected into the perivitelline space of an enucleated oocyte. Reconstructed oocytes were placed in holding medium of porcine zygote medium-3 (PZM-3) for 10-30 min until fusion treatment.

\section{Electrofusion/activation}

Reconstructed oocytes were electrically fused and activated. They were placed between two wire electrodes $1 \mathrm{~mm}$ apart, overlaid with $0.3-\mathrm{M}$ mannitol solution containing $0.05 \mathrm{mM}$ calcium chloride, $0.1 \mathrm{mM}$ magnesium sulfate and $0.5 \mathrm{mM}$ Hepes (Duchefa Biochemie, Haarlem, Netherlands). Two electric pulses of $1.25 \mathrm{kV} / \mathrm{cm}$ were applied for each $30 \mu \mathrm{sec}$ using an Electro Cell Manipulator 200 (BTX, San Diago, CA, USA). After electrofusion and activation, the reconstructed oocytes were placed in holding medium at $39^{\circ} \mathrm{C}, 5 \% \mathrm{CO}_{2}$ in air and examined for fusion.

\section{In vitro culture and sampling}

SCNT embryos were cultured in droplets of $30 \mu \mathrm{L}$ fresh PZM-3 medium at $39^{\circ} \mathrm{C}$ and $5 \% \mathrm{CO}_{2}$ in air for 6 days. After in vitro culture, the blastocysts were washed in PBS supplemented with 0.3\% (w/v) PVP (PBS-PVP). Subsequently, the blastocysts were lysed in $30 \mu \mathrm{L}$ of Lysis/Binding (L/B) buffer (Dynabeads ${ }^{\circledR} \mathrm{mRNA}$ Direct kit ${ }^{\mathrm{TM}}$ ), and stored at $-70^{\circ} \mathrm{C}$ until analyses.

\section{ER stress inhibitor treatments}

In treatment group 1 (NT+3 h group), micromanipulation was conducted in micromanipulation medium with $100 \mu \mathrm{M}$ TUDCA (Park et al., 2019), and subsequently fused SCNT embryos were cultured in PZM-3 medium containing $100 \mu \mathrm{M}$ TUDCA for $3 \mathrm{~h}$ prior to in vitro culture to ensure the inhibition of ER stress (Park et al., 2019).

In treatment group 2 (IVC group), micromanipulation was conducted in micromanipulation medium without TUDCA, then fused SCNT embryos were culture in PZM-3 medium with 100 $\mu \mathrm{M}$ TUDCA for 6 days.

In treatment group 3 (NT+IVC group), micromanipulation was conducted in micromanipulation medium with $100 \mu \mathrm{M}$ TUDCA, then fused SCNT embryos were culture in PZM-3 medium with $100 \mu \mathrm{MTUDCA}$ for 6 days.

Untreated SCNT embryos were used as control. 


\section{Cell number counting}

Some blastocysts of each groups were washed with PBS-PVP and stained with $20 \mu \mathrm{g} / \mathrm{mL}$ of Hoechst 33342 for $30 \mathrm{~min}$. Stained embryos were fixed on a slide glass and dropped the VectaShield (Vector Laboratories, Burlingame, CA, USA). Then, the slide glass was covered with a cover slip and the cell number of embryos was counted using a fluorescence microscopy (BX50, Olympus, Tokyo, Japan).

\section{9. mRNA extraction and cDNA synthesis}

Poly(A) mRNA of the SCNT blastocysts was isolated using a Dyna-beads ${ }^{\circledR}$ mRNA Direct ${ }^{\mathrm{TM}}$ kit according to the manufacturer's protocol. The cryopreserved embryo samples were melted and mixed with $40 \mu \mathrm{L}$ of Dynabeads oligo $(\mathrm{dT})_{25}$ and shaken for $8 \mathrm{~min}$ at room temperature to induce hybridization of poly $(\mathrm{A}) \mathrm{mRNA}$ tails with the oligo $(\mathrm{dT})_{25}$ on the beads. The beads with attached mRNA were washed twice with each $100 \mu \mathrm{L}$ of washing buffer $\mathrm{A}$ and B. Beads were separated from the supernatant using a DynaMag ${ }^{\text {TM }}$-Spin Magnet (Invitrogen, Carlsbad, CA, USA). Elution of the poly(A) mRNA from the beads was carried out by incubation with 12.5 $\mu \mathrm{L}$ of $10 \mathrm{mM}$ Tris- $\mathrm{HCl}$ (elution buffer) at $75^{\circ} \mathrm{C}$ for $5 \mathrm{~min}$. The cDNA synthesis was carried out using AccuPower ${ }^{\circledR}$ RocketScript ${ }^{\mathrm{TM}}$ Cycle RT Premix (Bioneer, Daejeon, Korea) according to the manufacturer's protocol. Each $10 \mu \mathrm{L}$ of mRNA was used for a template. The reaction was conducted by Veriti ${ }^{\circledR}$ 96-well Thermo cycler (Applied Biosystems, Foster City, CA, USA) at $4^{\circ} \mathrm{C}$ for $5 \mathrm{~min}$, followed by 5 cycles at $37^{\circ} \mathrm{C}$ for $15 \mathrm{sec}, 50^{\circ} \mathrm{C}$ for $5 \mathrm{~min}$, and $98^{\circ} \mathrm{C}$ for $5 \mathrm{~min}$. The cDNA products were conserved at $4^{\circ} \mathrm{C}$ before use.

\section{Semiquantitative polymerase chain reaction (semi-qPCR) and real-time quantitative PCR (RT-qPCR)}

The expression of X-box binding protein 1 (Xbp1) mRNA was detected by semi-qPCR. For semi-qPCR, cDNA samples were reverse-transcribed using the AccuPower ${ }^{\circledR}$ Taq PCR Premix (Bioneer) in accordance with the manufacturer's protocol. PCR condition was as follows: denaturation at $95^{\circ} \mathrm{C}$ for $30 \mathrm{sec}$, annealing at $60^{\circ} \mathrm{C}$ for $30 \mathrm{sec}$, and extension at $72^{\circ} \mathrm{C}$ for $5 \mathrm{~min}$. PCR products were analyzed by UV irradiation using a Gel Doc ${ }^{\mathrm{TM}} \mathrm{XR}+($ Bio-rad, Berkeley, CA, USA) on 4\% agarose gel (Amresco, Cleveland, OH, USA) containing 0.05\% ethidium bromide (Bioneer). ER stress-associated genes such as binding protein (BiP), glucose regulated protein 94 (GRP94), activating transcription factor 4 (ATF4), and C/ EBP homologous protein (CHOP), apoptotic genes such as $\mathrm{Bcl} 2$-associated $\mathrm{X}$ protein $(B a x)$ and caspase-3, and oxidative stress genes such as nuclear factor (erythroid-derived 2) 2 (Nrf2) and hemeoxygenase-1 (HO-1) were analyzed by RT-qPCR. RT-qPCR was carried out using $1 \mu \mathrm{L}$ of cDNA, $2 \mu \mathrm{L}$ of each primer pair, $3 \mu \mathrm{L}$ of sterile water (RNase free), and $6 \mu \mathrm{L}$ of $2 \mathrm{X}$ SYBR Green PCR master mix (TOPreal ${ }^{\mathrm{TM}} \mathrm{qPCR} 2 \mathrm{X}$ PreMIX; SYBR Green with high ROX, Enzynomics, Daejeon, Korea) in a StepOne Plus (Applied Biosystems). The amplification reaction was as follows: initial-denaturation at $95^{\circ} \mathrm{C}$ for $15 \mathrm{~min}$, followed by 40 amplification cycles of denaturation at $95^{\circ} \mathrm{C}$ for $15 \mathrm{sec}$, annealing at $60^{\circ} \mathrm{C}$ for 30 sec and extraction at $72{ }^{\circ} \mathrm{C}$ for $30 \mathrm{sec}$. The $\Delta \Delta \mathrm{CT}$ method (comparative CT method) was used to measure the relative mRNA quantification for respective target gene. Glyceraldehyde 3-phosphate dehydrogenase (GAPDH) was used as a housekeeping gene. The primer sequences for each gene used are listed in Table 1.

\section{Statistical analysis}

Statistical analysis was carried out using the Statistical Analysis System software (v.9.4, SAS Institute, Cary, NC, USA). PCR data were analyzed using the general linear model (GLM) and 
Table 1. All primer sequences used for RT-PCR and RT-qPCR

\begin{tabular}{|c|c|c|c|c|}
\hline Genes & $\begin{array}{c}\text { Primer sequences } \\
\left(5^{\prime}-3^{\prime}\right)\end{array}$ & $\begin{array}{l}\text { Length } \\
\text { (bp) }\end{array}$ & $\begin{array}{l}\text { GenBank } \\
\text { Acc No. }\end{array}$ & $\begin{array}{l}\text { Annealing } \\
\text { temp }\left({ }^{\circ} \mathrm{C}\right)\end{array}$ \\
\hline \multirow{2}{*}{ Xbp1 } & F-GGCAGAGACCAAGGGGAATG & \multirow{2}{*}{263} & \multirow{2}{*}{ FJ213449.1 } & \multirow{2}{*}{60} \\
\hline & R-GGGTCGACTTCTGGGAGCTG & & & \\
\hline \multirow{2}{*}{ BiP } & F-ACCAATGACCAAAATCGCCT & \multirow{2}{*}{246} & \multirow{2}{*}{ J03214.1 } & \multirow{2}{*}{60} \\
\hline & R-GTGACTTTCCAGCCACTCAA & & & \\
\hline \multirow{2}{*}{ GRP94 } & F-CTGCTGAAGGGGAA TTACC & \multirow{2}{*}{197} & \multirow{2}{*}{ Y09136.1 } & \multirow{2}{*}{60} \\
\hline & R-ATCATCTGAGTCCACAACGC & & & \\
\hline \multirow{2}{*}{ ATF4 } & F-TGAGCCCTGACTCCTATCTG & \multirow{2}{*}{277} & \multirow{2}{*}{ NM_001123078.1 } & \multirow{2}{*}{60} \\
\hline & R-TCCAGCTCTTTACATTCGCC & & & \\
\hline \multirow{2}{*}{$\begin{array}{l}\text { CHOP } \\
\text { (DDIT3) }\end{array}$} & F-AAGACCCAGGAAACGGAAAC & \multirow{2}{*}{261} & \multirow{2}{*}{ NM_001144845.1 } & \multirow{2}{*}{60} \\
\hline & R-TCCAGGAAAGGTCAGCAGTA & & & \\
\hline \multirow{2}{*}{$\begin{array}{l}\text { Nrf2 } \\
\text { (NFE2L2) }\end{array}$} & F-CCСАTTCACAAAAGACAAАCATTC & \multirow{2}{*}{72} & \multirow{2}{*}{ GU991000.1 } & \multirow{2}{*}{60} \\
\hline & R-GCTTTTGCCCTTAGCTCATCTC & & & \\
\hline \multirow{2}{*}{$\begin{array}{l}\text { HO-1 } \\
\text { (HMOX1) }\end{array}$} & F-CACTCACAGCCCAACAGCA & \multirow{2}{*}{162} & \multirow{2}{*}{ NM_001004027.1 } & \multirow{2}{*}{55} \\
\hline & R-GTGGTACAAGGACGCCATCA & & & \\
\hline \multirow{2}{*}{ Bax } & F-ACTGGACAGTAACATGGAGC & \multirow{2}{*}{294} & \multirow{2}{*}{ XM003127290.3 } & \multirow{2}{*}{55} \\
\hline & R-GTCCCAAAGTAGGAGAGGAG & & & \\
\hline \multirow{2}{*}{ Caspase-3 } & F-GAGGCAGACTTCTTGTATGC & \multirow{2}{*}{237} & \multirow{2}{*}{ NM_214131 } & \multirow{2}{*}{60} \\
\hline & R-CATGGACACAATACATGGAA & & & \\
\hline HAPR & F-GGGCATGAACCATGAGAAGT & 230 & $\triangle E 017070$ & 58 \\
\hline GAFDT & R-AAGCAGGGATGATGTTCTGG & 230 & ATUाण & 00 \\
\hline
\end{tabular}

the Duncan's multiple range test. Blastocyst formation rate was analyzed by Chi-square test, and the average cell number in blastocysts was analyzed by Student $t$-test.

\section{RESULTS}

\section{Effect of TUDCA on ER stress}

Xbp1 splicing tended to decrease in treatment groups (NT+3 h, IVC, and NT+IVC), but there was no significant difference from control group (23.4\%), and among treatment groups (14.5\%15.3\%, Fig. 1).

In the expression of ER stress-associated genes, the relative transcription levels of $C H O P$ in $\mathrm{NT}+3 \mathrm{~h}$ group and $A T F 4$ and $C H O P$ in IVC group were significant lower than those of control ( $p<0.05$, Fig. 2). In the NT+IVC group, the relative expression levels of all genes (BiP, GRP94, $A T F 4$, and $C H O P$ ) were significantly decreased compared to those of control $(p<0.05)$.

\section{Effect of TUDCA on oxidative stress}

In all treatment groups with ER stress inhibitor, the relative expression levels of oxidative stressrelated genes $\mathrm{Nrf2}$ and $\mathrm{HO}-1$, were significantly reduced compared to the control ( $p<0.05$, Fig. 3).

\section{Effect of TUDCA on apoptosis}

The relative expression levels of pro-apoptotic genes, Bax and caspase 3 mRNAs, were significantly decreased in all TUDCA treatment groups compared to the control ( $p<0.05$, Fig. 4). 

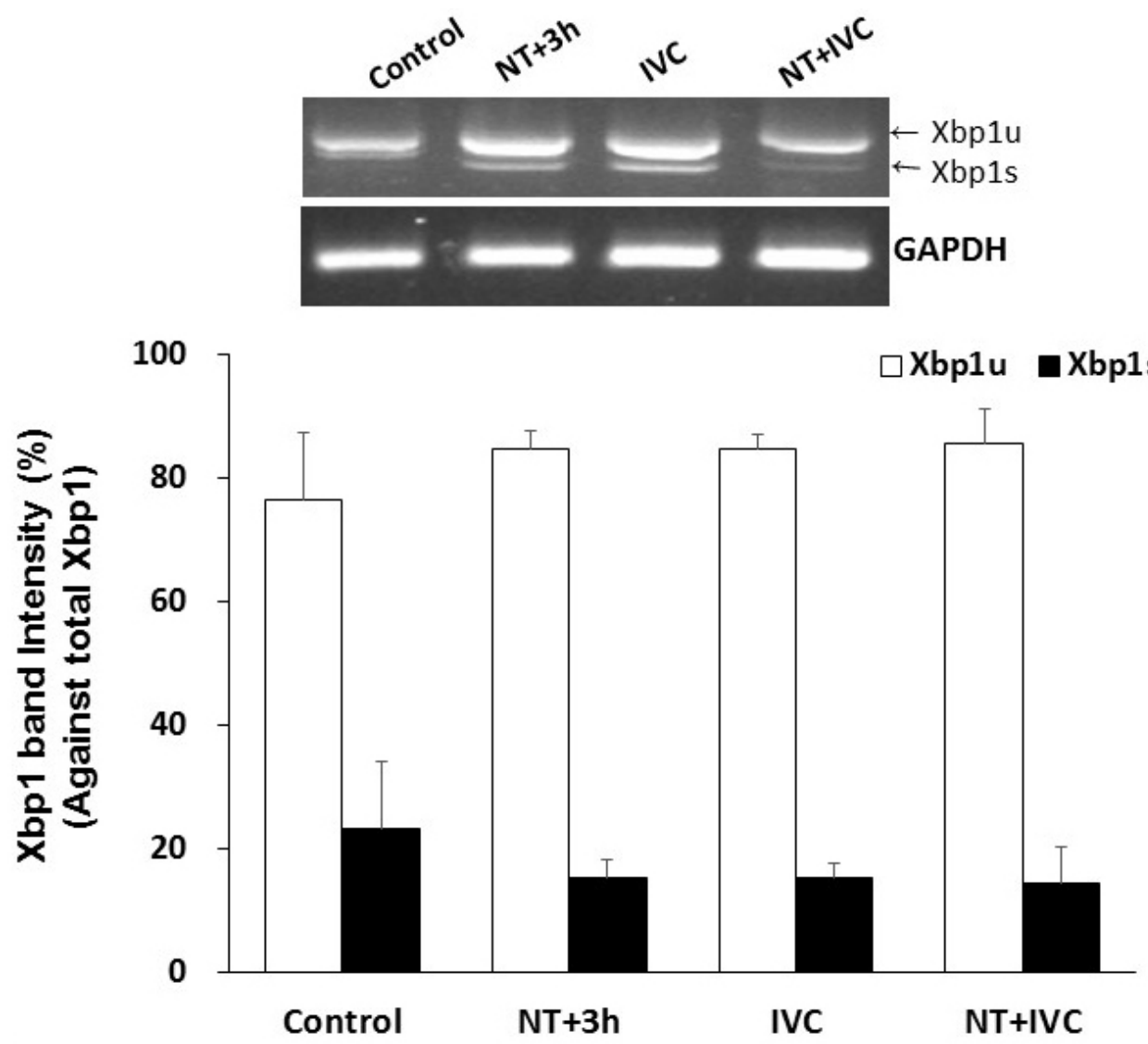

Fig. 1. Splicing level of Xbp1 mRNA in SCNT blastocysts. The mRNAs of unspliced Xbp1 (Xbp1u) and spliced Xbp1 (Xbp1s) were detected by semi-qPCR (upper panel) and band intensities (means $\pm S E M$ ) were measured densitometrically (lower panel). SCNT, somatic cell nuclear transfer. Xbp1, X-box binding protein 1.

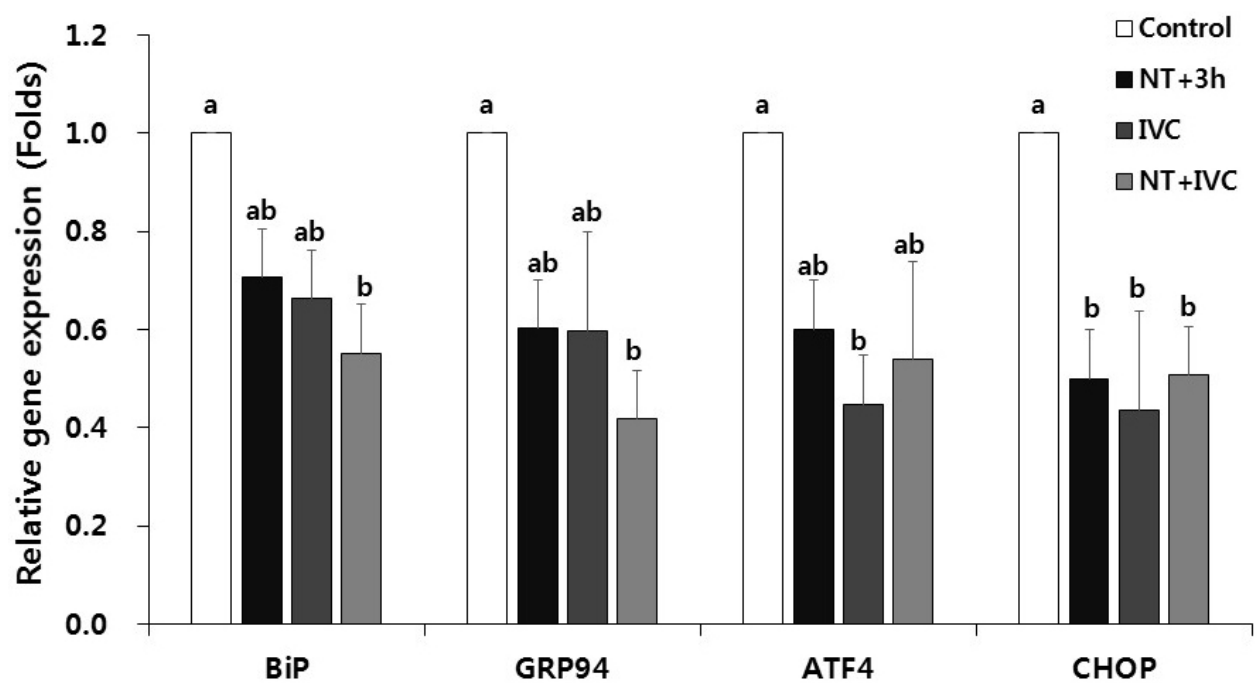

Fig. 2. ER stress-associated gene expression in SCNT blastocysts. ER stress-associated genes (BiP, GRP94, ATF4, and CHOP) were quantified by RT-qPCR (means \pm SEM). ${ }^{a, b}$ Values with different letters are significantly different $(p<0.05)$. ER, endoplasmic reticulum; SCNT, somatic cell nuclear transfer. 


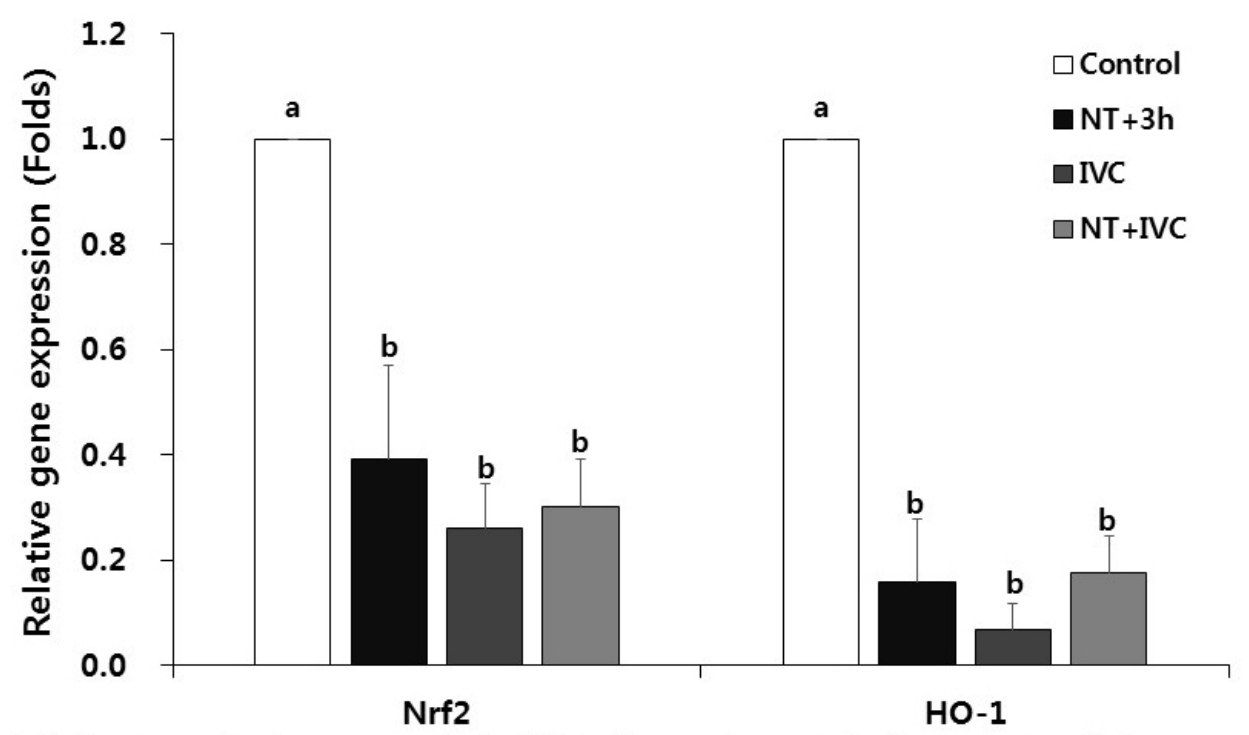

Fig. 3. Oxidative stress-related gene expression in SCNT blastocysts. Oxidative stress-related genes (Nrf2 and $H O-1$ ) were quantified by RT-qPCR (means \pm SEM). ${ }^{a, b}$ Values with different letters are significantly different $(p<0.05)$. SCNT, somatic cell nuclear transfer.

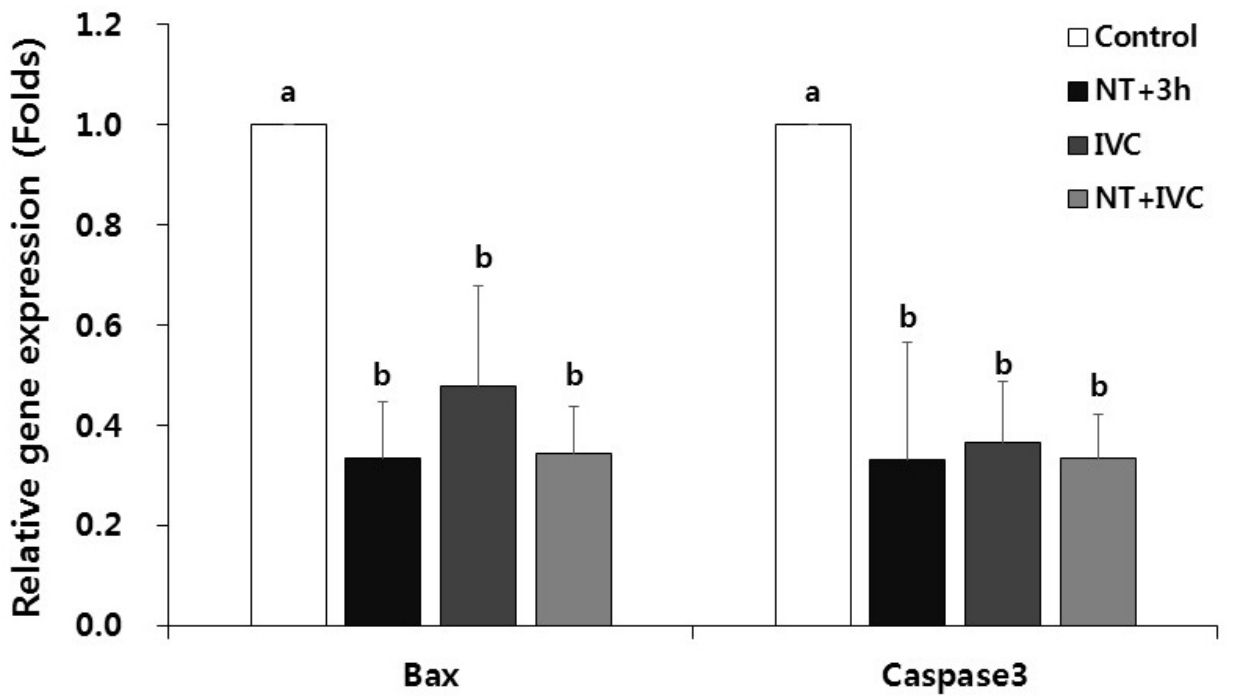

Fig. 4. Apoptotic gene expression in SCNT blastocysts. Apoptotic genes (Bax and caspase3) were quantified by RT-qPCR (means \pm SEM). $a, b$ Values with different letters are significantly different $(p<0.05)$. SCNT, somatic cell nuclear transfer.

\section{Effect of TUDCA on the in vitro development of SCNT embryos}

Developmental rate to the blastocyst stage tended to increase in all treatment groups, but there was no difference between the control and treatment groups and among treatment groups $(17.5 \%$ to $21.7 \%$, Table 2).

The mean cell number in blastocysts was significantly increased in NT+3 h (48.5 \pm 2.3$)$ group and NT+IVC group (47.7 \pm 2.4 ), but not IVC group (36.5 \pm 2.4$)$ compared to the control (35.3 \pm 2.5 , $p<0.05$, Table 2). 
Table 2. Effects of endoplasmic reticulum stress inhibitor treatment on the in vitro development of somatic cell nuclear transfer embryos

\begin{tabular}{lcccc}
\hline \hline \multirow{2}{*}{ Treatment } & $\begin{array}{c}\text { No. of } \\
\text { embryos } \\
\text { cultured }\end{array}$ & \multicolumn{2}{c}{ No. of embryos developed to } & $\begin{array}{c}\text { Cell no. in } \\
\text { blastocysts } \\
\text { (mean } \pm \text { SE) }\end{array}$ \\
\hline Control & 268 & $198(73.9)$ & $47(17.5)$ & $35.3 \pm 2.5^{\mathrm{a}}$ \\
NT+3 h & 270 & $208(77.0)$ & $56(20.7)$ & $48.5 \pm 2.3^{\mathrm{b}}$ \\
IVC & 273 & $207(75.8)$ & $55(20.1)$ & $36.5 \pm 2.4^{\mathrm{a}}$ \\
NT+IVC & 272 & $200(73.5)$ & $59(21.7)$ & $47.7 \pm 2.4^{\mathrm{b}}$ \\
\hline
\end{tabular}

Experiment was repeated more than 12 times in each treatment group.

a,b Values with different superscripts are significantly different $(p<0.05)$

\section{DISCUSSION}

When ER stress occurs, the inactivated $B i P$ is separated from the inositol-requiring enzyme 1 (IRE1), PKR-like ER kinase (PERK) and ATF6 by the accumulation of unfolded and misfolded proteins in the ER lumen and UPR is activated (Yoshida, 2007). Activated IRE1 $\alpha$ leads the splicing of Xbp1 mRNA (Schröder \& Kaufman, 2005; Hetz \& Glimcher, 2009). PERK-mediated phosphorylation of the $\alpha$-subunit of eukaryotic translation initiation factor 2 (elf2 $\alpha$ ) induces the activation of $A T F 4$, which stimulates the induction of $C H O P$ (Harding et al., 2000). Activated ATF6 regulates the transcriptions of GRP78, GRP94, XBP1, and CHOP (Yoshida et al., 2001).

Only spliced $X b p 1$ (Xbp1s) can enter the nucleus and control UPR-related genes. Xbp1s is reported to affect the maturation of oocytes and the activation of early embryonic genomes by suppressing the generation of ER stress (Zhang et al., 2012). In this study, the Xbp1 splicing following TUDCA treatment time tend to decrease in all treatment groups, but there was no difference from the control. It can be assumed that there was no difference in expression levels when $X b p 1$ was measured at the blastocyst stage, because some mechanism affecting the activation of the early embryonic genome occurred during the early cleavage stage.

In this study, ER stress-associated genes (BiP, GRP94, ATF4, and CHOP) were differently expressed depending on the treatment time of TUDCA. In the NT+3 h group, $C H O P$ expression was lower than that of the control, while in NT+IVC group the expression of all genes except ATF4 was lower than that of the control. According to the result of this study, as the treatment period increased, the number of ER stress-associated genes with significantly lower expression compared to control increased. Zhang et al. (2012) and Yoon et al. (2014) reported that the ER stress-related gene expression in the blastocyst stage was reduced when TUDCA was treated for culture period of porcine or bovine embryos. However, in other previous studies, when analyzing the ER stressassociated gene during the blastocyst stage, no significant difference was found between the ER stress inhibitor treatment group and control group (Park et al., 2019; Park et al., 2020). Meanwhile, in the previous study, the expression of Xbp1 and ER stress-associated gene at the 1-cell stage was significantly decreased in the TUDCA treatment group (Park et al., 2019; Park et al., 2020).

Nrf2, a higher factor in redox enzyme, is a typical transcription factor that responds to oxidative stress in cells (Cullinan \& Diehl, 2004). When ER stress occurs, ROS is generated while forming disulfide bonds in the folding of the protein, which results in oxidative stress and Nrf2 increases the expression of HO-1 through the Nrf2 pathway (Cullinan \& Diehl, 2006; Nguyen et al., 2009; Saito, 2013). In this study, the expression of oxidative stress-related genes decreased in all TUDCA treatment groups, which is similar to the previous result (Park et al., 2020). In the previous study, it was confirmed that the expression of $N r f 2$ and $\mathrm{HO}-1$ was reduced in the 1-cell stage of SCNT embryos by TUDCA treatment during porcine SCNT process, and the expression of $H O-1$ was 
also decreased in the blastocyst stage (Park et al., 2020).

In severe ER stress, $C H O P$ induced by the apoptotic pathway leads apoptosis by translocating the pro-apoptotic gene, Bax, from the cytoplasm to the mitochondria (Oyadomari \& Mori, 2004; Sano \& Reed, 2013). In addition, caspase12, which is a representative pro-apoptotic cysteine protease, activates caspase 3 in the downstream, leading to apoptosis (Oyadomari \& Mori, 2004). TUDCA reduces the translation of Bax into mitochondria membrane and inhibits the activation of caspase 12 by preventing the release of cytochrome c (Xie et al., 2002). In this study, the expression of apoptotic gene in all treatment groups was significantly lower than that of control. In particular, Bax mRNA level was relatively lower in NT+3 h and NT+IVC groups that treated with TUDCA during the micromanipulation process of SCNT than IVC group. The decreased expression level of $C H O P$ indicates that apoptosis induced by ER stress is inhibited. This is consistent with Park et al. (2020) reported that the expression of most ER stress-associated genes were reduced not only in the 1-cell stage but also in the blastocyst stage as a result of TUDCA treatment during the micromanipulation process.

In this study, although the expression of genes related to ER stress, ROS and apoptosis showed a tendency to decrease in all TUDCA treatment groups, the blastocyst development rate of SCNT embryos was not improved. The expression of genes in the blastocyst stage does not seem to have a direct effect on the development of SCNT embryos. However, the mean cell number in blastocysts in the NT+3 $\mathrm{h}$ and NT+IVC groups significantly increased compared to the control and IVC group. These results suggest that at least the quality of SCNT embryos can be improved by inhibiting or immediately reducing the ER stress during the initial micromanipulation process. These results are consistent with previous reports that ER stress inhibiter treatment during micromanipulation process of porcine SCNT can increase the blastocyst cell number rather than blastocyst development rate (Park et al., 2019; Park et al., 2020). On the other hand, in previous parthenogenesis and IVF studies, it was reported that the blastocyst development rate and cell number increased when TUDCA was treated during the IVC period (Kim et al., 2012). The reason for this difference is unclear, but in this study, the considerable physical stimulation of the SCNT process may have made this difference.

In conclusion, the result of this study suggests that treatment of ER stress inhibitor from the micromanipulation process of SCNT can improve the reprogramming efficiency of porcine SCNT embryos by inhibiting the ER and oxidative stresses that may occur early in the SCNT process.

\section{REFERENCES}

Boyce M, Yuan J (2006) Cellular response to endoplasmic reticulum stress: A matter of life or death. Cell Death Differ 13:363-373.

Cullinan SB, Diehl JA (2004) PERK-dependent activation of Nrf2 contributes to redox homeostasis and cell survival following endoplasmic reticulum stress. J Biol Chem 279:2010820117.

Cullinan SB, Diehl JA (2006) Coordination of ER and oxidative stress signaling: The PERK/Nrf2 signaling pathway. Int J Biochem Cell Biol 38:317-332.

Harding HP, Zhang Y, Bertolotti A, Zeng H, Ron D (2000) Perk is essential for translational regulation and cell survival during the unfolded protein response. Mol Cell 5:897-904.

Hetz C, Glimcher LH (2009) Fine-tuning of the unfolded protein response: Assembling the IRE1 $\alpha$ interactome. Mol Cell 35:551-556.

Hwang IS, Bae HK, Park CK, Yang BK, Cheong HT (2012) Generation of reactive oxygen species 
in bovine somatic cell nuclear transfer embryos during micromanipulation procedures. Reprod Dev Biol 36:49-53.

Kim JS, Song BS, Lee KS, Kim DH, Kim SU, Choo YK, Chang KT, Koo DB (2012) Tauroursodeoxycholic acid enhances the pre-implantation embryo development by reducing apoptosis in pigs. Reprod Dom Anim 47:791-798.

Lee HY, Bae HK, Jung BD, Lee S, Park CK, Yang BK, Cheong HT (2018) Analysis of endoplasmic reticulum (ER) stress induced during somatic cell nuclear transfer (SCNT) process in porcine SCNT embryos. Dev Reprod 22:73-83.

Lin T, Lee JE, Oqani RK, Kim SY, Cho ES, Jeong YD, Baek JJ,Jin DI (2016) Tauroursodeoxycholic acid improves pre-implantation development of porcine SCNT embryo by endoplasmic reticulum stress inhibition. Reprod Biol 16:269-278.

Malhotra JD, Kaufman RJ (2007) The endoplasmic reticulum and the unfolded protein response. Semin Cell Dev Biol 18:716-731.

Morgan HD, Santos F, Green K, Dean W, Reik W (2005) Epigenetic reprogramming in mammals. Hum Mol Gen 14:R47-R58.

Nguyen T, Nioi P, Pickett CB (2009) The Nrf2-antioxidant response element signaling pathway and its activation by oxidative stress. J Biol Chem 284:13291-13295.

Omura T, Asari M, Yamamoto J, Oka K, Hoshina C, Maseda C, Awaya T, Tasaki Y, Shiono H, Yonezawa A, Masuda S, Matsubara K, Shimizu K (2013) Sodium tauroursodeoxycholate prevents paraquat-induced cell death by suppressing endoplasmic reticulum stress responses in human lung epithelial A549 cells. Biochem Biophy Res Comm 432:689-694.

Oyadomari S, Mori M (2004) Roles of CHOP/GADD153 in endoplasmic reticulum stress. Cell Death Differ 11:381-389.

Park HB, Park YR, Kim MJ,Jung BD, Park CK, Cheong HT (2020) Endoplasmic reticulum (ER) stress inhibitor or antioxidant treatments during micromanipulation can inhibit both $\mathrm{ER}$ and oxidative stresses in porcine SCNT embryos. Dev Reprod 24:31-41.

Park YR, Park HB, Kim MJ,Jung BD, Lee S, Park CK, Cheong HT (2019) Effects of endoplasmic reticulum stress inhibitor treatment during the micromanipulation of somatic cell nuclear transfer in porcine oocytes. Dev Reprod 23:43-54.

Saito H (2013) Toxico-pharmacological perspective of the Nrf2-Keap1 defense system against oxidative stress in kidney diseases. Biochem Pharmacol 85:865-872.

Sano R, Reed JC (2013) ER stress-induced cell death mechanisms. Biochim Biophys Acta 1833:3460-3470.

Schröder M, Kaufman R (2005) ER stress and the unfolded protein response. Mutat Res 569:2963.

Sevier CS, Cuozzo JW, Vala A, Åslund F, Kaiser CA (2001) A flavoprotein oxidase defines a new endoplasmic reticulum pathway for biosynthetic disulphide bond formation. Nat Cell Biol 3:874-882.

Song BS, Yoon SB, Sim BW, Kim YH, Cha JJ, Choi SA, Jeong KJ, Kim JS, Huh JW, Lee SR, Kim SH, Kim SU, Chang KT (2014) Valproic acid enhances early development of bovine somatic cell nuclear transfer embryos by alleviating endoplasmic reticulum stress. Reprod Fertil Dev 26:432-440.

Xie Q, Khaoustov VI, Chung CC, Sohn J, Krishnan B, Lewis DE, Yoffe B (2002) Effect of tauroursodeoxycholic acid on endoplasmic reticulum stress-induced caspase-12 activation. Hepatology 36:592-601.

Yoon SB, Choi SA, Sim BW, Kim JS, Mun SE, Jeong PS, Yang HJ, Lee Y, Park YH, Song BS, Kim YH, Jeong KJ, Huh JW, Lee SR, Kim SU, Chang KT (2014) Developmental competence 
of bovine early embryos depends on the coupled response between oxidative and endoplasmic reticulum stress. Biol Reprod 90:1-10.

Yoshida H (2007) ER stress and diseases. FEBS J 274:630-658.

Yoshida H, Matssui T, Yamamoto A, Okada T and Mori K (2001) XBP1 mRNA is induced by ATF6 and spliced by IRE1 in response to ER stress to produce a highly active transcription factor. Cell 107:881-891.

Zhang H, Davies KJA, Forman HJ (2015) Oxidative stress response and Nrf2 signaling in aging. Free Radic Biol Med 88:314-336.

Zhang JY, Diao YF, Oqani RK, Han RX, Jin DI (2012) Effect of endoplasmic reticulum stress on porcine oocyte maturation and parthenogenetic embryonic development in vitro. Biol Reprod 86:1-9. 
